\title{
Komunikasi Antarbudaya dalam Perkawinan Beda Warga Negara
}

\author{
Lusiana Andriani Lubis ${ }^{1}$, Anang Jati Kurniawan², Syafruddin Pohan ${ }^{3}$ \\ ${ }^{1,2,3}$ Program Studi Magister Ilmu Komunikasi, Fakultas Ilmu Sosial dan Ilmu Politik, \\ Universitas Sumatera Utara \\ Jl. Dr. Sofyan No.1 Kampus Medan, 20222 Indonesia \\ Email: Lus1ana_andr1an1@yahoo.com ${ }^{*}$; anangjk17@gmail.com²; pohansyafruddin@usu.co.id ${ }^{3}$ \\ *Corresponding author
}

\begin{abstract}
The purpose of the research is to analyze the process of inter-cultural communication in married couples of different nationalities namely Indonesia and Foreign in Medan City. In addition, analyzing the barriers of intercultural communication experienced in married couples are different citizens. The method used is qualitative with a case study approach to 4 (four) citizens taken in purposive sampling. Data collection techniques are conducted in in-depth interviews and live observations. Data analysis is written in the form of an inductive and interactive narrative that is case by case based on the category that has been formulated. The findings show that the inter-cultural communication process runs in accordance with the cultural experience and knowledge that each marriage partner has with a pre-nuptial agreement such as religious transfer, views on values and behaviors and language used. Barriers to inter-cultural communication are overcome by the shared commitment to be able to and get used to different things and learn to understand each other's spouses as consequences of a different marriage of citizens. The contribution of this research is in the form of recommendations for families to apply heart-to-heart communication to establish a mutual commitment to intercultural communication. Keywords: Different Nationalities; Intercultural Communication; Marriage
\end{abstract}

\begin{abstract}
Abstrak
Tujuan penelitian adalah menganalisis proses komunikasi antarbudaya pada pasangan suami istri beda Warga Negara yaitu Indonesia dan Asing di Kota Medan. Selain itu menganalisis hambatan komunikasi antarbudaya yang dialami pada pasangan suami isteri beda warga negara. Metode yang digunakan adalah kualitatif dengan pendekatan studi kasus kepada 4 (empat) orang warga negara yang diambil secara purposive sampling. Teknik pengumpulan data dilakukan secara wawancara mendalam dan pengamatan langsung. Analisis data ditulis dalam bentuk naratif induktif dan bersifat interaktif yaitu kasus demi kasus berdasarkan kategori yang telah dirumuskan. Hasil temuan menunjukkan proses komunikasi antarbudaya berjalan sesuai dengan pengalaman budaya dan pengetahuan yang melatarbelakangi masing-masing pasangan perkawinan beda warga negara dengan kesepakatan sebelum menikah seperti perpindahan agama, pandangan terhadap nilai dan perilaku serta bahasa yang digunakan. Hambatan komunikasi antarbudaya diatasi dengan adanya komitmen bersama, yaitu harus bisa dan terbiasa dengan hal-hal yang berbeda dan belajar memahami pasangannya masing-masing sebagai konsekuensi dari perkawinan beda warga negara. Kontribusi penelitian ini berupa rekomendasi kepada keluarga untuk menerapkan komunikasi hati ke hati untuk menjalin komitmen kebersamaan dalam komunikasi antarbudaya. Kata kunci: Beda Warga Negara; Komunikasi Antarbudaya; Perkawinan
\end{abstract}

\section{Pendahuluan}

Perkawinan antara Warga Negara Indonesia (WNI) dengan Warga Negara Asing (WNA) bukan menjadi hal yang asing lagi di Indonesia saat ini, termasuk di Provinsi Sumatera, terkhusus di kota Medan yang terkenal dengan masyarakat berbilang kaum dan budaya. Tidak hanya perkawinan campur antar etnis pribumi yang berbeda namun juga perkawinan antara pribumi dan warga negara asing. Perkawinan campuran dengan warga asing dalam perundang-undangan di Indonesia, didefinisikan dalam Pasal 57 UUD

No.1 Tahun 1974 (Pemerintahan Indonesia, 1974): "Perkawinan campuran dalam Undangundang ini ialah perkawinan antaradua orang yang di Indonesia tunduk pada hukum yang berlainan, karena perbedaan kewarganegaraan dan salah satu pihak berkewarganegaraan asing dan salah satu pihak berkewarganegaraan Indonesia". 
Perkawinan yang terjadi antara Warga Negara Indonesia (WNI) dengan Warga Negara Asing (WNA)diaturdalamUndang-UndangPerkawinan Republik Indonesia No.1 tahun 1974, pasal 59 ayat 2, bahwa (Pemerintahan Indonesia, 1974):

"Perkawinan antara dua orang yang berbeda kewarganegaraan atau dengan perkataan lain perkawinan antar bangsa adalah perkawinan antara warga negara Indonesia dengan warga negara asing".

Komunikasi antarbudaya adalah proses komunikasi yang berlangsung antara orangorang yang berbeda latar belakang pengetahuan dan pengalaman budaya, baik sebagai komunikator maupun komunikan dalam pemaknaan pesan yang saling dipertukarkan untuk menghasilkan efek yang harmonis di antara kedua pihak yang berkomunikasi (Lubis, 2018a; Mulyana, 2019). Proses komunikasi antarbudaya menunjukkan upaya yang sadar dari peserta komunikasi untuk memperbaharui hubungan antara komunikator dan komunikan, membangun manajemen komunikasi yang efektif, kesetiakawanan, persahabatan, sampai kepada mengurangi ketidakpastian dan konflik antarbudaya (Liliweri, 2018).

Setiap pasangan berbeda kewarganegaraan mengalami hambatan dalam berkomunikasi antarbudaya seperti fenomena gunung es yang dapat dibagi menjadi dua yaitu berada di atas air (above waterline) dan berada di bawah air (below waterline). Faktor-faktor hambatan komunikasi antarbudaya yang berada dibawah air adalah faktor-faktor yang membentuk perilaku atau sikap seseorang (Lubis, 2018a: 5-6). Hambatan semacam ini cukup sulit untuk diperhatikan atau dilihat, sebagaimana dikatakan Lubis (2018b:13) bahwa orang asing atau pendatang yang melintasi batas budaya tuan rumah dilihat dari pengalaman, pengetahuan dan tujuan, tetapi harus menyesuaikan perilaku komunikasinya dengan pengaturan budaya baru tuan rumah yang didatanginya. Individu tersebut membawa serta budayanya, bahasa, nilai-nilai, agama dan lainnya, tidak jarang menimbulkan kecemasan dan ketegangan yang disebut dengan gegar budaya. Komunikasi antarbudaya adalah suatu proses komunikasi yang perlu dipahami oleh pasangan perkawinan dengan perbedaan kewarganegaraan tersebut.

Peres dan Schift (2011) menekankan bahwa pasangan suami istri dengan latarbelakangbudaya yang berbeda dapat saling berbagi pandangan, pengalaman dan makna agar mampu membangun pengertian bersama melalui komunikasi. Pasangan yang tidak berbagi perspektif, maka pasangan dapat mempersepsi peristiwa atau situasi secara berbeda dan rasa kecewa terhadap perkawinan muncul dan akhirnya menurunkan kualitas hubungan dalam perkawinan.

Kurniawan, Wulandari, Manurung, dan Manurung (2017) dalam penelitiannya menegaskan bahwa perkawinan beda warga negara harus dapat menjaga intensitas komunikasinya. Tujuannya adalah agar hubungan yang sudah dibina berdasarkan cinta dapat berjalan harmonis setiap waktu dan berusaha memahami kekurangan yang ada pada masing masing diri menjadi sebuah kekuatan dalam menjalani kehidupan.

Penelitian Yolanda dan Susanto (2018) juga mendapati bahwa adanya hambatan pasangan perkawinan beda warga negara dalam berkomunikasi dilihat dari pola pikir dan bahasa sehingga memerlukan penyesuaian diri lebih lama. Penelitian Lubis (2012a dan 2012b) menambahkan bahwa komunikasi antarbudaya etnis Tionghoa dan Pribumi dapat mengubah cara pandang seseorang terhadap nilai-nilai budaya dan bahasa yang digunakan, sehingga dapat mendorong perilaku seseorang untuk bertindak sesuai dengan apa yang diinginkannya.

Penelitian Nurhadi, Hendrawan, dan Ayutria (2019) menemukan model komunikasi antarbudaya pelaku perkawinan campur berkaitan dengan pengalaman, makna dan stereotip. Komunikasi merupakan faktor utama dalam keberhasilan membina perkawinan 
antarbudaya (Houseworth, 2008:11). Dengan demikian komunikasi penting untuk menyatakan identitas dan integritas sosial, serta penghubung untuk kesamaan makna antara pasangan (Septiana, Krisnatuti, dan Simanjuntak, 2014).

Berdasarkan latarbelakang yang ada, penelitian ini bertujuan untuk menganalisis proses komunikasi antarbudaya pada pasangan suami istri beda Warga Negara yaitu Indonesia dan Asing di Kota Medan.

\section{Metode Penelitian}

Penelitian ini menggunakan metode kualititatif, yang bertujuan mempertahankan bentuk dan isi perilaku manusia serta menganalisis kualitasnya (Creswell, 2016). Metode kualitatif tidak mengutamakan besarnya populasi dan sampel, tetapi bagaimana data dapat digali secara mendalam dari para informan meskipun jumlah sampelnya terbatas. Jika datanya sudah terkumpul secara mendalam dan dapat menjelaskan masalah yang diteliti maka tidak perlu mencari sampling lainnya. Pendekatan kualitatif memungkinkan penulis memberi penjelasan komprehensif tentang fenomena tertentu, tidak hanya sekedar memberikan generalisasi terhadap fenomena tersebut. Penggunaan pendekatan kualitatif penulis juga dapat mempelajari interaksi simbolis antar manusia dalam beragam bentuk dan konteksnya. Data riset kualitatif, periset adalah bagian integral dalam menentukan jenis data yang diinginkan (Kriyantono, 2014; Bungin, 2013).
Penulis menggunakan studi kasus, sebagaimana dikatakan Creswell (2016) bahwa studi kasus sebagai suatu penelitian empiris yang menyelidiki fenomena dalam konteks kehidupan nyata, sebagaimana batasan-batasan antara fenomena dan konteks tak tampak dengan jelas, dan dimana multisumber bukti dimanfaatkan. Populasi perkawinan beda warga negara di Medan banyak, namun angka pasti yang menikah secara resmi tidak didapatkan penulis. Penentuan sampling dilakukan secara purposive sampling (sampel bertujuan) dengan kareteristik yang telah ditetapkan oleh penulis yaitu suami istri, beda warga negara, menikah, tinggal di Medan dan bersedia diwawancarai. Pengumpulan data melalui wawancara mendalam dan observasi (Herdiansyah, 2013).

Berdasarkan kriteria tersebut, ada 4 (empat) keluarga yang bersedia di wawancarai secara mendalam yaitu: 1). George Hubberd dan Desy Prima Suaka (Inggris-Indonesia), 2) Hans Kilsch dan Lili Juana Sari Sembiring (Jerman-Indonesia), 3) Heri Prayitno dan Louise Moore (Indonesia dan Inggris), dan 4) Roberto Marastoni dan Endah Ayu Lestari (ItaliaIndonesia). Selain wawancara mendalam juga pengamatan langsung (observasi partisipan) dilakukan dengan keluarga informan khususnya ke rumah Desy dan George, juga keluarga Hans dan Lili sebab berada di Kota Medan sehingga memudahkan penulis ke lapangan.

Tabel 1. Karakteristik Informan Pasangan Suami Istri Beda Warga Negara

\begin{tabular}{|c|c|c|c|c|c|c|}
\hline No & Uraian & & Informan I & Informan II & Informan III & Informan IV \\
\hline \multirow[t]{2}{*}{1} & \multirow{2}{*}{ Nama } & Suami & George Hubberd & Hans Kilsch & Heri Prayitno & Roberto Marastori \\
\hline & & Istri & Desy Prima Suaka & Lili Juana Sari Sembiring & Louise Moore & Endah Ayu Lestari \\
\hline 2 & Warga Negara & Suami & Inggris & Jerman & Indonesia & Italia \\
\hline \multirow[t]{2}{*}{3} & \multirow{2}{*}{ Usia } & Suami & 73 Tahun & 64 Tahun & 31 Tahun & 57 Tahun \\
\hline & & Istri & 41 Tahun & 48 Tahun & 38 Tahun & 38 Tahun \\
\hline 4 & Agama & Suami & Islam & Islam & Islam & Islam \\
\hline 5 & Pendidikan & Istri & SMA & Sarjana & Master & Sarjana \\
\hline \multirow[t]{2}{*}{6} & \multirow{2}{*}{ Pekerjaan } & Suami & Konsultan & Wiraswasta & Pramu Wisata & Wiraswasta \\
\hline & & Istri & Ibu Rumah Tangga & Wiraswasta & Instruktur Yoga & Wiraswasta \\
\hline 7 & Usia Pernikahan & 25 Tahun & 24 Tahun & 5 Tahun & 3 Tahun & \\
\hline 8 & Jumlah Anak & 4 & 1 & - & 2 & \\
\hline
\end{tabular}

Sumber: Hasil olahan peneliti (2019) 
Analisis data kualitatif dalam bentuk naratif induktif dan bersifat interaktif (Ahmadi, 2016:231). Tahapan reduksi data melalui seleksi, penyederhanan permasalahan data berdasarkan sudut pandang informan dan memberikan perhatian kepada jawaban informan yang berhubungan satu dengan yang lainnya dalam bentuk naratif induktif. Data disajikan berupa uraian teks kasus per kasus. Pada akhirnya penulis melakukan verfikasi dari sumber teori dan kajian terdahulu sebelum menarik kesimpulan.

\section{Hasil Penelitian dan Pembahasan}

Penelitian ini berlangsung selama 5 (lima) bulan yaitu Februari hingga Juni 2019. Katrekteristik para informan seperti yang terlihat pada tabel 1 .

Pada tabel 1 dilihat secara jelas karekteristik informan. Uraian singkat hasil wawancara dengan masing-masing informan seperti yang diuraikan di bawah ini.

\section{Informan 1: George Hubberd (Muhammad Yusuf) dan Desy Prima Suaka}

Pasangan suami istri yang mempunyai empat orang anak ini merupakan pribadi yang sangat ramah dan sopan. George sudah lama tinggal di Indonesia, lebih kurang 25 (dua puluh lima) tahun pernikahannya dengan Desy dan memiliki 4 (empat) orang anak dan satu di antaranya sudah tamat kuliah sarjana (S1) di Medan. George memberikan nama kepada putera puterinya nama yang biasa digunakan di kampung halamannya yaitu Inggris, meskipun anak-anak mereka dilahirkan di Indonesia. Beliau lama di Jakarta dan kemudian pindah ke Medan dan sampai pensiun menetap di Medan.

Beberapa hal yang dirasakan pada pasangan iniadalah permasalahan budaya dalamlingkungan internal keluarga dan juga dengan lingkungan di sekitarnya. Saat menikah dengan Desy, George memutuskan meninggalkan agamanya Kristen Katolik dan sepakat dengan pasangannya untuk menganut agama Islam. George bahkan melakukan penggantian nama menjadi Muhammad Yusuf setelah beliau menganut agama Islam. George mengatakan perubahan ke agama Islam adalah satu kesepakatan dengan Desy dan pilihan yang tepat agar keluarganya mempunyai satu agama yang jelas, ikut Dady atau Mami (panggilan akrab pasangan di rumah).

Pada awal pernikahan, George belum sepenuhnya menjalankan ibadah sesuai aturan pada Agama Islam. Hal ini berpengaruh kepada Desy dalam menjalankan ibadahnya. Desy mengatakan bahwa yang dikatakan suaminya itu betul adanya bahwa "awalnya dia juga belum menjalankan ibadah sebagai seorang muslimah sejati. Hal ini baru dapat terlaksana setelah lebih kurang dua puluh tahun (20 tahun)". Desy hijrah dalam menjalankan syariah sesuai dengan aturan yangberlakudiagamaIslam, sepertimenggunakan hijab dan rutinitas melaksanakan sholat lima waktu sesuai tuntunan dalam Agama Islam. Perubahan perilaku dan kebiasaan Desy yang sebelumnya tidak jauh berbeda dengan kebiasaan perempuan di Eropa yang biasa diketahui George mulai berubah menjadi lebih santun. Lambat laun George juga ikut melaksanakan kewajibannya sebagai seorang Muslim.

George sempat dibingungkan dengan tutur kata yang ada di Indonesia mengenai pemanggilan 'abang' dan 'kakak'. Penuturan abang untuk laki-laki yang umurnya lebih tua dan kakak untuk perempuan yang berumur lebih tua, sesuatu hal yang sangat wajar di Indonesia. Berbeda dengan kebudayaan George yaitu kebudayaan Inggris, mereka tidak mengenal panggilan tersebut. Dalam bahasa Inggris hanya dikenal kata 'brother' yang ditujukan kepada saudara laki-laki dan 'sister' kepada saudara perempuan. Kedua kata ini hanya menerangkan tentang jenis kelamin saudara, tidak menerangkan tingkatan usia dan tidak untuk panggilan sehari-hari. George meyakini bahwa "semua orang mempunyai nama, dan ingin disebut dengan nama yang dimiliki". 
Hasil observasi langsung ke keluarga George dan Desy, di rumah menggunakan bahasa Inggris, begitu juga dengan anak-anaknya. Bagi Desy ini suatu hal yang positif mempelajari bahasa Inggris, bahkan kemampuan bahasa Inggrisnya lebih baik daripada George dalam berbahasa Indonesia. Bu Desy mengatakan bahwa "bahasa tidak menjadi hambatan besar asalkan kita mau mempelajarinya".

Selain itu, kebiasaan George adalah minum bir dan selalu membawa bir di tempat khusus. Kebiasaan minum bir merupakan kebudayaan beliau yang dibawanya dari Inggris. George selalu membawa kotak penyimpanan untuk minuman bir kemanapun beliau pergi. George bahkan mempunyai kotak penyimpanan bir di dalam kendaraannya. Meskipun Desy sedikit keberatan dengan kebiasaannya ini karena Desy mengganggap bahwa "kebiasaan George tersebut tidak sesuai dengan lingkungannya di Kota Medan, tetapi beliau tetap melakukan kebiasaannya meminum bir".

Selain kebiasaan George minum bir, George juga sangat suka membaca buku, sehingga beliau memiliki waktu-waktu khusus yang tidak bisa diganggu saat beliau membaca. Kebiasaan George membaca buku biasanya dilakukan pada hari libur. Menurut Desy: "George tetap berada di satu ruangan dengan anggota keluarga yang lain, tetapi beliau lebih fokus dengan buku bacaannya dan baru berbincang-bincang dengan keluarganya apabila beliau sudah merasa selesai membaca bukunya" (Wawancara berlangsung di rumah George dan Desy yang beralamat di komplek Setiabudi Vista pada pukul 19.47 wib pada tanggal 18 Juni 2019).. Observasi penulis langsung dengan keluarga Desy mendapati bahwa penggabungan kebudayaan ini terlihat pada perpaduan arsitektur rumah mereka. George membuat ruang kerja yang sekaligus ruang bacanya bergaya Eropa. Begitu juga dalam hal pemilihan perabot rumah tangga, artistik dengan perpaduan dari kayu jepara.
Informan 2: Hans Kilsch dan Lili Juwana Sari

Hans Kilsch lahir pada tahun 1955 di Kota Konstans Jerman. Hans Kilsch mempunyai seorang saudara laki-laki yang sampai saat ini tinggal di kota tersebut. Hans mempunyai 3 (tiga) gelar kesarjanaan yaitu Ekonomi, Hukum, dan Teknik Sipil. Beliau pernah mengikuti wajib militer di Jerman selama 2 (dua) tahun. Hans Jurgen mengurus usaha keluarga yaitu penginapan di Bukit Lawang yang dinamakan 'Trekking Lodge', yang menyukai olah raga sepeda tersebut. Istri beliau, Lili Juwana lahir di Kota Medan tahun 1971, pendidikan terakhir Ibu Lili adalah sarjana bahasa inggris dari Universitas Islam Sumatera Utara. Menikah dengan Hans pada tahun 1995 dan pasangan ini dikaruniai seorang anak perempuan. Pasangan ini pertama sekali berjumpa pada wadah organisasi Generasi Muda Islam Karo (GMIK). Kesamaan minat dalam berorganisasi, bersepeda, dan pola hidup sehat membuat keduanya mudah untuk saling beradaptasi. Kemampuan Lili dalam berbahasa inggris dan Hans yang juga fasih berbahasa Indonesia mempererat hubungan keduanya.

Hans dibesarkan secara Kristen, tetapi dia memutuskan untuk mengubah keyakinannya dan mengikuti agama yang dianut Lili yaitu agama Islam saat menikah. Hans mengatakan "agama tidak dijadikan permasalahan bagi Hans sebab satu syarat yang harus dipatuhi dalam keluarga Lili”. Setelah memeluk Islam keduanya menikah dan diadati dengan menggunakan adat Karo dalam pesta pernikahan.

Begitupun Hans tetap mempertahankan kebudayaan yang dimilikinya saat beliau masih tinggal di Jerman, dimana turun temurun selalu mengadakan pertemuan keluarga di dapur rumahnya. Kebiasaan ini tetap dilestarikan hingga saat ini dengan Lili di Medan. Alasan pemilihan dapur ini dikaitkan dengan kemudahan mengakses makanan yang ada di dapurnya, sehingga sewaktu Hans menikah dengan Lili beliau merancang ruang dapur dengan gaya Eropa dan dirancang dengan 
senyaman mungkin. Hans berkata: "Di Jerman kita lebih banyak ngobrol di ruangan dapur, karena itu dapur saya buat senyaman mungkin."

Hambatan komunikasi dalam hal bahasa tidak ada sebab Lili mampu dalam menggunakan bahasa Inggris dan Hans yang juga mahir berbahasa Indonesia mengakibatkan hilangnya kendala dalam berkomunikasi. Lili juga dapat berbahasa Jerman secara pasif, hal ini disebutkan Lili: "Kami berkomunikasi dengan menggunakan bahasa Indonesia karena Hans mau belajar bahasa Indonesia dan beliau rajin baca kamus. Saya mengerti bahasa Jerman, tetapi agak susah untuk diucapkan karena di dalam bahasa Jerman terlalu banyak kata kerja”. Keluarga Lili yang sebagian besar akademisi khususnya abang kandung dari orang tua lakilaki Lili yang pernah menyelesaikan studi di Jerman, sangat membantu pasangan ini untuk dapat lebih memahami tentang kebudayaan satu sama lain. Hal ini dikatakan oleh Lili dalam wawancara menyatakan "Saya mempunyai keluarga yang pernah tinggal lama di Jerman, beliau banyak memberikan masukan mengenai bagaimana kebudayaan orang Jerman".

Hans dan Lili mengalami hambatan komunikasi tentang kebiasaan Lili yang konsumtif. Hans mengatakan: 'Pola hidup istrinya konsumtif dan untuk itu saya harus bersabar". Hans juga merasakan bahwa perempuan di Indonesia lebih emosional bila dibandingkan dengan perempuan di Jerman. Sifat emosional yang cepat marah dan cemburu dianggap Hans sebagai perilaku yang harus diubah pasangannya. Meskipun begitu Hans merasa bahwa perempuan di Indonesia juga tertutup dalam mengungkapkan perasaannya. Perasaan marah dan cemburu yang dirasakan oleh pasangannya tidak langsung diungkapkannya. Hal ini menurut Hans merupakan sesuatu yang sangat berbahaya, karena semua permasalahan dalam rumah tangga harus dibicarakan dan diselesaikan secepatnya.
Hans merasakan perbedaan dalam hal mengasuh anak. Beliau membandingkan cara mengasuh anak di Jerman dengan di Indonesia. Menurut Hans, orang tua di Indonesia terlalu mempercayakan anak kepada asisten rumah tangga (pembantu rumah). Orang tua di Indonesia dinilai memanjakan anak, bukan mendidik anak. Hans mengatakan: "Tugas orang tua bukan memanjakan anak tetapi mendidiknya dan membuatnya mandiri. Anak di Jerman mandiri dengan cara tidak membujuknya apabila menangis kecuali lapar dan buang air" (Wawancara berlangsung terpisah, Lili tanggal 21 Juni 2019 jam 19.30 di Medan dan Hans tanggal 25 Juni 2019 jam 16.30 di Bukit Lawang).

\section{Informan 3: Heri Prayitno dan Louise Moore}

Perkenalan pasangan ini berawal dari saat Heri Prayitno ditugaskan menjadi guide Louise Moore pada kegiatan Help Orang Utan di Bukit Lawang. Heri sebutan akrabnya mengatakan beliau tertarik dengan Louise Moore karena intensitas pertemuan yang menjadikan mereka lebih dekat. Beliau mengagumi sifat Louise Moore yang dianggapnya pintar, terbuka, dan mandiri. Louise adalah seorang vegetarian, meskipun Louise memasak untuk anggota keluarga yang lain di rumahnya seperti suami dan mertuanya, beliau tetap memasak makanannya sendiri yang berupa sayur-sayuran. Louise juga tetap menggunakan bahasa Inggris di lingkungannya. Tingkat pendidikan Louise yang tinggi dan keinginannya untuk mempelajari kebudayaan Indonesia menyebabkan Louise dapat beradaptasi dengan cepat pada lingkungannya. Kenyamanan dalam berkomunikasi dengan Louise dirasakan oleh Heri: "Saya merasa cocok dan nyaman berkomunikasi dengan Louise".

Heri juga mengizinkan istrinya untuk memasak masakannya sendiri yang hanya berupa sayur dan buah-buahan, beliau bahkan sering memakannya sepulang dari pekerjaannya. Louise yang menggunakan hijab apabila menghadiri acara keagamaan di lingkungan 
mereka. Louise juga menyatakan kekagumannya dengan rasa kekeluargaan dari pihak suaminya. Louise bahkan dapat menentukan berapa menit yang harus ditambahkannya apabila beliau diundang oleh pihak keluarga Heri.

Louise merasakan hambatan tentang kebiasaannya menggunakan tangan kiri dalam mengambil sesuatu. Heri mengatakan menggunakan tangan kiri disini tidak sopan. Louise juga merasakan perbedaan disiplin yang ada di Indonesia dan beliau kurang menyukai orang Indonesia yang tidak disiplin terhadap waktu. Begitu juga dengan masalah kemandirian, Louise merasa Heri tidak mandiri karena masih sangat tergantung dengan orang tuanya. Beliau mengatakan "Saya sendiri sudah hidup mandiri sejak berumur 18 tahun" (Wawancara di Bukit Lawang, tanggal 26 Juni 2019 pukul 11.30 wib)

\section{Informan 4: Roberto Marastoni Italia dan Endah Ayu Lestari}

Roberto Marastoni lahir di Kota Milan Italia tahun 1962, pendidikan terakhir beliau Superiore Bernocchi atau setingkat Sekolah Menengah Umum. Endah Ayu Lestari, lahir di Kota Medan tahun 1982, Pendidikan terakhir S1 Sarjana Hukum. Kegiatan pasangan ini adalah Eksport Import kopi danjugamengelola pabrik pembuatan coklat milik mereka di Kota Milan. Pasangan ini pertama sekali berjumpa di pertemuan yang diadakan oleh SCAA (Specialty Coffe Association of America) di Kota Seattle Amerika Serikat pada tahun 2015. Roberto menyukai pribadi Endah yang dianggapnya sebagai seorang yang profesional, mandiri, sopan, dan penyayang. Endah tertarik dengan kedewasaan Roberto yang dianggapnya sangat memahami ambisinya. Endah mempunyai seorang putra dari pernikahan sebelumnya yang bernama Sultan Naradi, dan tinggal bersama dengan pasangan tersebut. Pasangan ini juga mempunyai rumah di Kota Milan Italia, dan dikarenakan usaha yang mereka jalankan bersama mereka sering melakukan perjalanan Italia dan Indonesia.
Pasangan Roberto dan Endah keseharian menggunakan bahasa Inggris dan Italia. Endah berusaha keras belajar bahasa Italia karena bisnis yang dilakukannya di Italia dan lebih banyak tinggal di Italia dibandingkan di Indonesia. Anak Endah dari suaminya yang pertama yaitu Sultan Naradi sangat mahir menggunakan bahasa Italia karena mereka menyekolahkan Sultan pada Sekolah Dasar di Italia. Roberto selalu terbuka kepada istrinya, kebiasaan lain yang dimiliki Roberto adalah selalu menyempatkan waktu untuk berbincang-bincang sore hari di halaman belakang rumah mereka. Kebiasaan ini juga didapat Roberto dari keluarganya secara turun temurun. Endah juga mengerti kebiasaan berbincang-bincang yang dimiliki oleh keluarga suaminya, meskipun beliau tidak menyukai perbincangan yang panjang, dan lebih bersikap sebagai pendengar yang baik.

Selain itu, Roberto dalam pemeliharaan budayanya adalah kebiasaan makan malam pada perayaan Tahun baru. Kegiatan ini dilakukan mulai dari jam 8 (delapan) malam sampai jam 12 malam saat pergantian Tahun. Roberto dan Endah tetap mengikuti kebiasaan keluarga Roberto ini meskipun telah menganut Agama Islam. Endah berkata: "Pergantian tahun selalu kumpul bersama merayakan pergantian tahun sepanjang tidak menyalahi aturan Agama Islam, seperti meminum minuman keras dan memakan daging yang diharamkan pada ajaran Agama Islam". Untuk pasangan ini, Roberto menjalankan ibadah sebagai seorang Muslim dengan baik. Beliau melakukan sholat, puasa dan juga berqurban. Endah berperan membantu suami dalam hal ibadah sebab perpindahan agama kepada Islam. Endah berkata: "Saya harus mengingatkan suami untuk sholat lima waktu, puasa di bulan Ramadhan, Qurban. Dia mau mengikuti arahan saya dan saling mengingatkan untuk kebaikan" (Wawancara melalui telepon seluler, karena pasangan ini sedang berada di Italia. Tanggal 26 Juni 2019, Pukul 14.22) 
Terlihat hasil wawancara dan obsevasi yang dilakukan peneliti dengan para informan memiliki perbedaan latar belakang budaya. Perbedaan latar belakang budaya yang dimiliki masingmasing informan dalam penelitian ini berbeda karena setiap kebudayaan mengajarkan cara-cara tertentu untuk memproses informasi yang masuk dan keluar dari atau ke lingkungan sekeliling mereka. Latar belakang pengalaman (Field of Experience) dan latar belakang pemikiran (Frame of Reference) menjadi satu yang tidak bisa dipisahkan bagi pasangan informan. Perpaduan kedua budaya atau lebih tanpa menghilangkan budaya asal (akulturasi) menunjukkan bahwa identitas budaya masih tetap terpelihara. Komunikasi antarbudaya dari berbagai perilaku subkultur tertentu dalam kelompok masyarakat dapat dijadikan alat perekat membangun kebersamaan (togetherness) untuk tujuan dan tercapainya kepentingan bersama atas dasar saling mencintai, saling menghormati dan saling mempercayai di antara pasangan yang terikat dalam pernikahan (Lubis, 2018b; Solomon, 2013). Berapa hal yang menarik perhatian penulis dari wawancara dengan informan yaitu Agama, Nilai dan Perilaku, serta Bahasa.

\section{Agama}

Agama adalah satu yang hak dan pedoman bagi manusia yang menuntun arah kehidupan kepada ketenangan, ketenteraman dan tunduk patuh kepada sang pencipta. Data temuan menunjukkan keempat informan mengikuti keyakinan pasangannya yang beragama Islam. George awalnya Kristen Katolik, tetapi sebelum melakukan pernikahan sepakat dengan pasangannya Desy untuk menganut agama Islam. George bahkan melakukan penggantian nama menjadi Muhammad Yusuf setelah beliau mualaf. Begitu juga dengan Hans, Roberto dan Louise masuk Islam karena pasangannya. Pada sistem pengetahuan, semua informan mempelajari kebudayaan pasangannya sebelum mereka memutuskan untuk menikah.
Mulyana (2019) menyatakan bahwa pandangan keagamaan seseorang membentuk kepercayaan kepada Tuhan, nilai-nilai, dan mengubah sikap dan perilaku sesuai ajaran yang dianut. Analisis penulis bahwa proses komunikasi imigran mendasari pengetahuan dan pengalaman budayanya yang ditransfer dari pengalaman tuan rumah dalam hal ini pasangannya melalui identifikasi dan internalisasi pemahaman keagamaan yang terus menerus (Lubis, 2018b: 10).

\section{Nilai dan Perilaku}

Keempat informan mempunyai kematangan dalam berkeluarga, sehingga dapat mengontrol diri terhadap pasangannya dan berusaha menghindari konflik budaya. Pandangan dunia masing-masing individu terhadap nilai yang dianut membawa kebaikan pada keluarga. Semua pasangan memilih damai dalam menghadapi masalah, seperti kebiasaan yang tidak bisa dihindari George dari minum Bir, Hari perokok berat, Lili pencemburu dan konsumtif, Louise vegetarian dan tidak suka bermain main dengan waktu, dan Endah yang ambisius dalam bisnisnya. Namun keempat pasangan tujuan yang sama untuk menjaga keseimbangan dalam keluarga. Satu hal yang unik dari penelitian ini adalah penggabungan kebudayaan pada segi arsitektur bangunan rumah yang mana semua pasangan menggabungkan arsitektur Eropah dan Indonesia pada rumah mereka dan perabotan rumah. Kecuali pasangan Heri dan Louise karena mereka masih tinggal di rumah orang tua Heri. Intinya adalah akulturasi budaya berlangsung disini, bahwa adanya kerinduan kepada kampong halaman dan situasi di rumah bersama keluarga besar menjadi wujud dalam keluarga barunya.

Penulis melihat akulturasi seorang imigran dari perspektif komunikasi terdapat pada sistem yang dielaborasi dengan situasi saat ini. Akulturasi mengacu kepada proses dimana budaya seseorang dimodifikasi melalui kontak atau pemaparan langsung dengan budaya tuan 
rumah (Lubis, 2018b: 21). Selain itu suasana alamiah informan dan berusaha menutupi kekurangan yang ada suatu yang patut dipuji. Oberg (Antropolog) mengatakan individu yang berbeda membawa pola budaya orang tua, keluarga atau kelompoknya kepada suatu arena petualangan yang tidak terlepas dari suasana problematik yang harus dikuasai sesulit apapun agar kegelisahan yang mengendap tidak muncul dari kehilangan semua lambang dan simbol yang familiar dalam hubungan sosial (Lubis, 2018b:14-15). Juga sejalan dengan penulisan Lubis (2012a:17) bahwa komunikasi antarbudaya merupakan suatu proses dinamis yang dilakukan oleh manusia melalui perilaku yang berbentuk verbal dan non-verbal (isyarat, gerakan, bahasa tubuh) yang dikirim dan diterima serta ditanggapi oleh orang lain dengan latar belakang budaya yang berbeda.

\section{Bahasa}

Bahasa verbal dan non-verbal merupakan suatu yang harus dipikirkan oleh pasangan yang memutuskan untuk memilih pasangan beda warga negara. Umumnya informan dan pasangannya mengerti dan berkemampuan berbahasa Indonesia ataupun bahasa Inggris sebagai bahasa sehari-hari di antara pasangan. Informan Endah mengalami hambatan dalam berbahasa Italia karena beliau menetap di Italia dan bisnis kopinya menuntutnya harus mampu berkomunikasi dengan bahasa tempatan. Beliau tetap berusaha menguasai bahasa Italia dalam interaksi sosial di luar rumah dan bisnisnya, sedangkan di rumah menggunakan bahasa Inggris dengan keluarga. Hal ini perlu diperhatikan dalam komunikasi antarbudaya sebab bahasa adalah peta realitas budaya yang tidak dapat dialihkan secara sempurna ke dalam suatu bahasa lain. Bahkan satu katapun tidak selalu secara tepat dapat dicarikan padanannya dalam bahasa lain (Lubis, 2012b: 287).

\section{Simpulan}

Berdasarkan uraian di atas, proses komunikasi antarbudaya berjalan sesuai dengan pengalaman budaya dan pengetahuan yang melatarbelakangi masing-masing pasangan perkawinan beda warga negara. Adanya komunikasi dari hati ke hati sehingga munculnya kesepakatan di antara pasangan beda warga negara sebelum menikah seperti keputusan perpindahan agama. Pandangan terhadap nilai dan perilaku merupakan pengalaman yang dirasakan pasangan beda warga negara setelah pernikahan dan lambat laun dapat diatasi dengan adanya usaha bersama untuk saling memahami dan melengkapi kekurangan yang ada. Bahasa yang digunakan pasangan beda warga negara tidak menjadi hambatan yang serius sebab bahasa yang digunakan sehari-hari adalah bahasa Inggris dan bahasa Indonesia. Kecuali pada tempat umum mengikuti kebiasaan masyarakat sebagai salah satu kearifan lokal yang perlu dipahami. Hambatan komunikasi antarbudaya ada dan berusaha diatasi seperti kebiasaan minum bir, merokok, menggunakan tangan kiri, kurang disiplin terhadap waktu, rasa cemburu dan konsumtif. Hal ini dapat diatasi dengan adanya komitmen bersama harus bisa dan terbiasa dengan hal-hal yang berbeda dan belajar memahami pasangannya masing masing sebagai konsekuensi dari perkawinan beda warga negara. Kontribusi penelitian ini berupa rekomendasi kepada keluarga untuk menerapkan komunikasi hati ke hati untuk menjalin komitmen kebersamaan dalam komunikasi antarbudaya.

\section{Ucapan Terima Kasih}

Penulis berterima kasih kepada para informan yang membantu penulisan ini.

\section{Daftar Pustaka}

Ahmadi, R. (2016). Metodologi Penelitian Kualitatif. Yogyakarta: Ar-Ruzz Media. Bungin, Burhan. (2013). Metodologi Penelitian Sosial dan Ekonomi: Format Penelitian Kuantitatif dan Kualitatif untuk Studi Sosiologi, 
Kebijakan Publik, Komunikasi, Manajemen dan Pemasaran. Jakarta: Kencana. Creswell, J.W. (2016). Research Design: Pendekatan Metode Kualitatif, Kuantitatif dan Campuran. Edisi Keempat. Yogyakarta: Pustaka Pelajar. Herdiansyah, H. (2013). Wawancara, Observasi dan Focus Groups sebagai Instrumen Penggalian Data Kualitatif. Jakarta: Rajawali Pers. Houseworth, C. (2008). Determinants of Intermarriage in the United States. The Humanities and Social Sciences, 68(12), 514. Kurniawan, A. J., Wulandari, E., Manurung, M. E., \& Manurung, N. E. (2017). Aculturation in Mixed Marriage Family (A Case Study In The Inter-Cultural Communication In Javanese And Tionghoa In Medan). International Journal of Scientific \& Technology Research, 6(7), 21-25. Kriyantono, R. (2014). Teknis Praktis Riset Komunikasi. Jakarta: Kencana Prenada Media. Liliweri,Alo. (2018). Prasangka, Konflik dan Komunikasi Antarbudaya. Jakarta: Prenadamedia Group.

Lubis, L. A. (2012a). Komunikasi Antarbudaya Etnis Tionghoa dan Pribumi di Kota Medan. Jurnal Ilmu Komunikasi, 10(1), 13-27. Diakses dari http://jurnal.upnyk. ac.id/index.php/komunikasi/article/view/83

Lubis, L. A. (2012b). Komunikasi Antarbudaya Tionghoa dan Pribumi dalam Penggunaan Bahasa. Jurnal Ilmu Komunikasi, 10(3), 285-294. Diakses dari http://jurnal.upnyk. ac.id/index.php/komunikasi/article/view/46

Lubis,L.A.(2018a). PemahamanPraktis Komunikasi Antarbudaya. Cet.ke-3. Medan: USU Press. Lubis, L. A. (2018b). Perkawinan Antaretnis: Dalam Kajian Komunikasi Lintas Budaya. Medan: USU Press. Mulyana, Deddy. (2019). Pengantar Komunikasi Lintas Budaya; Menerobos Era Digital Dengan Sukses. Bandung: Remaja Rosdakarya.
Nurhadi, Z.F., Hendrawan. H. dan Ayutria, D.F. (2019). Model Komunikasi Antarbudaya Keluarga Mixed Marriage di Wilayah Budapest-Hungaria. Jurnal ASPIKOM, 3(6), 1140-1152. http:// dx.doi.org/10.24329/aspikom.v3i6.331

Pemerintah Indonesia. (1974). Undang-Undang Perkawinan Republik Indonesia No.1 Tahun 1974 Pasal 59 Ayat 2. Lembaran RI Tahun 1974. Jakarta: Sekretariat Negara. Peres, Y., \& Schrift, R. (2011). Intermarriages and Interethnic Relations. Ethnic and Racial Studies, 1(4), 428-451.

Romano, Dugan. (2008). Intercultural marriage: promises and Pitfalls. 3 rd ed. Boston: Intercultural Press.

Sanjaya, A. (2013). Hambatan Komunikasi Antarbudaya antara Staf Marketing dengan Penguni Berkewarganegaraan Australia dan Korea Selatan di Apartemen X Surabaya. e-Jurnal Komunikasi, I(3),252-263. Diakses dari http://publication.petra.ac.id/index. php/ilmukomunikasi/article/view/939 Septiana, V. S., Krisnatuti, D.dan Simanjuntak, M. (2014). Faktor Suku dalam Pola Komunikasi, Penyesuaian Suami Istri dan Keharmonisan Keluarga. Jurnal Ilmu Keluarga \& Konsumen, 7(1), 1-9. https://doi.org/10.24156/jikk.2014.7.1.1

Solomon, C. (2013). Connecting Interracial Relationships to Polynesian Culture. Colloquy, 9, 21-38. Venus, Antar. (2013). Fenomenologi Komunikasi Perkawinan Antarbudaya. Jurnal Ilmu Komunikasi, 2(2), 1-14. Diakses dari https://jkms.ejournal.unri. ac.id/index.php/JKMS/article/view/2548 Yolanda, H. \& Susanto, E. H. (2018). Komunikasi Interpersonal dan Komunikasi Antarbudaya di antara Pasangan Suami Istri berbeda Kewarganegaraan. Koneksi, 2(1), 74-80. http://dx.doi.org/10.24912/kn.v2i1.2432 